\title{
'I Only Hate Broccoli' : The Library as Place in 21st Century America"
}

Wayne A. Wiegand**

\begin{abstract}
By taking a bottom-up "library in the life of the user" perspective rather than a top-down "user in the life of the library" perspective, this paper uses anecdotal evidence from the past and near present to examine the multiple roles the U.S. public library plays and has played as public space in the everyday lives of its patrons. By harnessing "public sphere" theory discussed in Jürgen Habermas's THE STRUCTURAL TRANSFORMATION OF THE PUBLIC SPHERE (1989) and by the examining the rich literatures on civic life and institutions that have evolved from it, the author argues that Library and Information Studies discourse has to expand its scope to include research and analysis of "library as place" from a user's perspective if it hopes to develop a deeper understanding of what the public library does for means to members of the communities in which they reside.
\end{abstract}

Keywords: Library as Place, Public Libraries, USA, Library History, Public Sphere

* The paper was originally presented at the International Conference commemorating the 40th Anniversary of the Korean Society for Library and Information Science held in Seoul, Korea on October 8, 2010.

** F. William Summers Professor of Library and Information Studies Florida State University Tallahassee, Florida, USA(wwiegand@fsu.edu)

논문접수일자: 2010년 9월 5일 최초심사일자: 2010년 9월 16일 게재확정일자: 2010년 10월 6일 한국문헌정보학회지, 44(4): 61-74, 2010. [DOI:10.4275/KSLIS.2010.44.4.061] 
For a history of the American public library I am currently researching I recently visited three libraries in the State of Montana. At the Parmly Billings Library in Billings, I met with library staff and patrons to learn about several initiatives recently undertaken, among them an annual event called "Food for Thought: An Evening of Great Conversation" that encouraged the gathering of community and exchange of free thought (each table was hosted by a moderator expert in a particular subject); "Raging Flood Waters: Billings' Gloomiest Night" (a travelling exhibit of a June 11, 1937, flood that devastated the town), a program called "Can We Talk? A Community Conversation" (a Humanities Montana event to promote civil public discourse that is modeled on Gracious Space: A Practical Guide for Working Better Together put out by the Center for Ethical Leadership in Seattle, Washington), and "Project Homeless Connect", an annual one-day, one-stop event to connect Billings' homeless and near-homeless population to resources that provide a "hand up and out of poverty." Pretty impressive array of community programs, I thought to myself.

At the Bozeman Public Library, I was also impressed with public programming. Just inside the front door, for example, is a large community room--used for lots of purposes, I was told. At the time I was in the building scores of toddlers were being read to by parents. When I peeked inside I met 83 year old Ray Bequet, a volunteer who reads and enjoys the company of children nearly every day. "For some reason", he said, "my smile appeals to kids." (Hausen, 2008). What especially caught my eye at Bozeman, however, was the artwork and sculpture that adorned the building. Greeting me at the front door was an eight-foot bronze sculpture by Mitch S. Billis depicting a youth holding a book on the back of a winged horse. Once inside I looked up into the soaring heights to see suspended sculptures representing clouds done by local artist Richard Parish and donated by the Friends of the Library. Adorning the walls of one very long hallway were decades-old framed posters of the Union Pacific Railroad, which had a huge influence on Bozeman history. As I looked into the children's room, above the door was a quotation from Alice in Wonderland: "What's the use of a book", thought Alice, "without pictures or conversations." Inside the room children's artwork plastered the walls. The Library had won a 2003 National Award for Library Service from the Institute for Museum and Library Services for, among many other activities, working with the Montana Center for International Visitors to sponsor evening programs on the fabrics of Bangladesh and ecotourism in Mongolia, and shortly after 9/11 for sponsoring a program entitled "What Is Islam?"

At the Flathead County Library in Kalispell I learned about a project run by an organization called "Flathead on the Move." The project--entitled "Principles for Civil Dialogue: Turning 
Strangers into Neighbors"-- was designed to provide safe space in which people can discuss diverse opinions and respectfully disagree without shouting at each other. Organizational meetings for "Flathead on the Move" occurred in the Library, which has been an active partner in "Principles for Civil Dialogue" since it began. What drew my attention most, however, was a series of incidents Library Director Kim Crowley told me had occurred earlier in the year. Because the Library followed the American Library Association's recommended Library Bill of Rights and years earlier instituted a policy that its assembly room was open to anyone in the community, it did not hesitate when a local white supremacist group called "Kalispell Christian Fellowship" scheduled meetings to show two films- "Epic: The Story of the Waffen SS" (which takes a positive spin on the Nazi war machine) and "The Truth Behind the Gates of Auschwitz", a Holocaust denial film. Predictably, local opponents rallied. At the first film showing hundreds of protesters appeared with placards that read "No Neo-Nazis" and "No Hate in My Backyard." The second also drew hundreds of protestors with similar placards, some promoting peace, others denouncing hatred. "I only hate broccoli", read a sign a local rabbi carried. I asked Kim how she felt about these incidents: "Isn't it better to know who these people are, and know that a white supremacist group exists in this valley, than to have them meeting secretly in someone's garage or house?" she responded. "Though the two groups disagreed (sometimes loudly and angrily), there were conversations going on everywhere between the two groups. And at the second one, I was thrilled to see 300 people at the library for an event! It was really great to see all the public discourse happening." Ironically, she noted, "both sides thanked me separately for allowing this to happen." (Crowley, 2010).

Discerning readers/listeners may see a theme in the Montana library activities I highlight here. All involve use of the library as public space, in which - as these examples illustrate-community gathers, debates, participates, displays, and gets constructed in various ways. None directly involve information technology, use of which not only dominates the subject material of this conference and now drives the curricula of library and information studies programs across the globe, it also has preoccupied the library profession for a quarter century.

In a essay entitled "Libraries and the Invention of Information" (Wiegand, 2007) I wrote for the Blackwell Companion to the History of the Book (the editor gave me that title), I argue that so much of librarianship's professional attention has been devoted to the provision of information and the technologies being harnessed to serve it that we now routinely define modern-day librarianship as part of an "age of information." And since the late 1970s (remember Alvin Toffler's Future Shock [1970] and Wilf Lancaster's Towards Paperless 
Information Systems [1978]) professional leaders have attempted to redefine librarianship from an "education" to an "information" profession, and at the same time to position librarianship as a major player in this "age of information" in which the word "information" itself has been redefined - one might even say "invented"-by ever changing information technologies.

Although I am not blindly critical of the direction this has taken us, at the same time I note that despite predictions made by many evangelists of information technology since 1980 suggesting libraries would not last out the $20^{\text {th }}$ century (I was tempted to search the publications of folks at this conference to see if any here made similar predictions), American Library Association statistics clearly demonstrate that turnstile counts at American libraries have only increased in the last fifteen years. Why is this happening? A large part of the answer to that question can, I think, be found by investigating the "library as place", and that the best way we can discover the roles library as place play--not only in sustaining these ubiquitous civic institutions but also increasing their importance--is to shift our perspective from "user in the life of the library" (which privileges the transactional services preoccupying practicing professionals) to "library in the life of the user" (which instead empowers the patron and makes her the agent of action). To explain those growing numbers of turnstile counts, we have to deepen our knowledge of how and why people use libraries as places.

Let me first start with a philosophical concept. Libraries constitute institutions occupying spaces and providing places in the "public sphere", a term more fully defined by philosopher Jurgen Habermas (Habermas, 1989). In the $18^{\text {th }}$ century, Habermas argues, the growing middle classes carved out a sphere of influence between governments and marketplaces that they exercised through new institutions (e.g., political parties, periodicals, and newspapers) and places (e.g., coffee houses, pubs, and parks). In his book, The Good Citizen, Michael Schudson says "public sphere" refers to "both a public forum independent of government and to private associations beyond the household where people come together to discuss public affairs." The public sphere, he concludes, "is the playing field for citizenship." (Schudson, 1998)

While my visits to three Montana public libraries certainly provide vivid examples of how as place the American public library functions as a playing field for citizenship, they are hardly exhaustive. To deepen understanding of how library spaces fill needs in the everyday lives of patrons, we need to import a new vocabulary into LIS studies drawn from other disciplines concerned with the public sphere and the public realm. I start with Tony Hiss's The Experience of Place. "One part of experiencing places has to do with changing the way we look at things, diffusing our attention and also relaxing its intensity", he argues. "A change that lets us start 
to see all the things around us at once and yet also looks calmly and steadily at each one of them." Quiet places do that. They "invite people to redistribute their attention." Active spaces, which "welcome experiencing", do that too. Sometimes people want "a long sweeping vista" where "viewing is unhindered" and where individuals can "take in information for miles around." Sometimes they seek "refuge" in "hiding places", where they can "see without being seen" and can "gain information without giving away information." All offer environmental stimulation, but in different ways and for different purposes. All "become a space" for people because individually they appropriate it differently in their everyday lives.

A public place also must be "spatially anchored", affording individuals reasons to frequent it- "the more reasons they have, the more secure they feel and the more time they"ll spend there; they'll visit more often, and they'll make longer visits." Public places also offer opportunities to find "a little niche" where individuals "can stand or sit without being bothered by other people and without getting in anyone's way." And they spend time in public places for two kinds of reasons - passive (people watching, drinking a cup of coffee while reading a newspaper) and active (talking to friends, meeting someone) (Hiss, 1990). Note words and phrases like "refuge", "become a space”, "welcome experiencing”, "spatially anchored." They don't show up much in our professional discourse, and without a vocabulary like this we deny ourselves opportunities to develop a deeper understanding of "library as place."

In a 1997 book Ray Oldenburg introduced the phrase "third place" that has recently found its way into our literature. First place, he argues, is home; second place is work. A third place, however, functions as one of the "core settings of informal public life" offering escape from home and work and "neutral ground" where people are not required to host, can gather, feel comfortable with each other, and come and go as they please. Third places keep long hours, function as "levelers" where social class differences are less important, and are accessible and accommodating. They also have "regulars"--often individuals who find this third place more comfortable than their first and second places. Third places maintain a low profile and fit ordinary patterns of daily routine. They make people feel rooted, provide emotional warmth, cultivate a sense of ownership and belonging, and empower people by allowing them to select when to participate in community behaviors, and when just to watch. And within safe space they also offer the prospect of seductive uncertainties (unpredictable topics of conversation, diversity of behaviors and experiences). In third places, the right of free assembly is constantly on public display, but not in the form of organized associations. Rather, third places foster informal social associations where people are treated as individuals, not as objects or customers. 
And those who frequent third places regularly play influential roles in controlling behaviors; over time they learn acceptable habits and help enforce civic responsibility by all who interact there. They make possible the socialization of community behaviors and thus contribute to social and community harmony (Oldenburg, 1997). They are the "playing field for citizenship" in the everyday lives of those who frequent these places. "Escape", "neutral ground", social "leveling", places that foster "conversation", are "accessible and accommodating"--all words and phrases Oldenberg introduces into public place vocabulary. In libraries we see these kinds of interchanges every day, but still we haven't figured out ways to measure their social benefits for the bean counters who want to set rules for identifying the value of library services.

In The Public Realm: Exploring the City's Quintessential Social Territory Lyn Lofland sees three kinds of places - a "private realm" where individuals are connected by ties of intimacy, a "parochial realm" where members are involved in interpersonal networks and linked by a sense of community, and a "public realm" in which "individuals in copresence tend to be personally unknown or only categorically known to one another." The latter is social territory that can simultaneously support and sustain a variety of biological and cultural strangers. Public realms provide learning environments - not formal learning environments like schools and universities, but an informal kind occurring in everyday cultural life. They also constitute communication centers - not the kind made possible by information technologies, but the kind that provide places where people talk to each other face-to-face. It's a place they practice personal politics - not the kind manifested by Democrats and Republicans, but the kind essential to ironing out differences and constructing social and community compromises. "The public realm is one of the very few kinds of social territories that, on a recurring basis, provides the opportunity for individuals to experience limited, segmental, episodic, distanced links between self and other", Lofland argues. "The public realm is, in fact, probably the locus for a significant portion of all noncommunal, nonintimate relations that humans form with one another." (Lofland, 1998). "Learning", "communication", "politics"--more words that seem familiar, but with a new "public realm twist" Lofland adds them to the vocabulary helping us understand what happens in public space.

My last author is Linda Most, who wrote a doctoral dissertation at Florida State University on the three public libraries in Gadsden County, just west of Tallahassee. It is one of the poorest counties in the state and the nation, and one of the few in Florida that has an African American majority. Linda took conclusions and observations Hiss, Oldenburg, Lofland and others developed, then applied them to her own observations of how Gadsden County residents used 
their public libraries as places. She found that the libraries provided neutral sites that functioned not only as informational places, but also as familiar locations that encouraged a sense of belonging where the community's social capital was generated and exchanged. "The new libraries are among the very few places in the county where library users can encounter visitors, guest speakers, and other people different from themselves", she noted. "As such, they bring a touch of cosmopolitanism to their small towns." (Most, 2009) I saw something else in her dissertation, however. For residents of Gadsden County, who had known racial strife and discrimination in the recent past and to a large extent still practiced racial separation in their churches and social organizations, the Gadsden County Library system boldly put "racial harmony" on public display for anyone who entered. Symbolically, this place delivered an essential message to outsiders about their home.

As a library historian I can easily prove that the library as community center has had a long history all the way back to the Alexandrian Library where Greek scholars gathered in spaces designed to facilitate communication, many of which still inspire library architects. And every one of those thousands of buildings Andrew Carnegie donated at the turn of the $20^{\text {th }}$ century had community rooms, which were actually given priority over workspace for librarians. That people used them was obvious from an article Arthur P. Kellogg published in a 1914 issue of Survey magazine entitled "Small Town Rejuvenated: How a Society Center Has Succeeded New Community Spirit." In it he describes a public library donated by a local wealthy family that included a billiard room, a community shower and bathtub, a small bank to encourage children to save, a domestic science classroom, and "a well-lighted and ventilated auditorium accommodating about 200 people." (Kellogg, 1914). This physical plant enabled the library to host community entertainments, fairs, socials, and physical education classes for town youths. Eleven years later the Wisconsin Library Bulletin argued "the library should be a social center" containing an auditorium and meeting rooms for women's and girls' clubs, Boy Scouts, and men's debating societies (Wisconsin Library Bulletin, 1925).

My wife Shirl and I are currently researching a book on the desegregation of public libraries in the American South. African American communities in Savannah, Georgia, Greensboro, North Carolina, and Louisville, Kentucky, managed to obtain Carnegie grants, and because so much public space was denied them in Jim Crow South the buildings Carnegie funded quickly became community centers for local cultural events. The same was true for segregated neighborhoods in northern cities, as the Carter G. Woodson Regional Library in Chicago and the Alfonse Schomburg Center in New York City bear witness. And when southern public 
library systems desegregated between 1954 and 1968 African American communities with their own branches hesitated; they placed such high value on their libraries as places, they worried that sharing library space with whites would deprive them of opportunities to exchange social capital and celebrate and profile black culture.

By mid-century, librarians had done such a good job of what they thought was their primary professional imperative-collecting books that contained vital information they regarded as "essential to democracy" (a very Jeffersonian principle) - that the books actually crowded out the community space. In Carnegie buildings, most often this meant Children's Rooms were relocated in former community rooms, while stacks crowded into space the Children's Rooms vacated on the first floor. As a result, the concept of library as social center slipped out of our professional discourse for two generations; only recently has it reappeared (Buschman \& Leckie, 2007; Wiegand, 2005; Leckie, 2004; Leckie and Hopkins, 2002)—often, ironically, as if it was something new to the practice of librarianship.

But by that time librarianship had turned from an "education" to an "information" profession (some even argued "the information profession") in which the word "information" was defined by technology. And with Wilf Lancaster's seminal book, many began predicting the demise of the library. That myth has raised its hoary head ever since, and finds its way into all sorts of justifications for not funding libraries. In 2002, for instance, a Tacoma, Washington, local councilman wanted to eliminate local public libraries because "as we see them today" they "are somewhat of a dinosaur--too intensive on bricks and mortar." Besides, he argued, it's all on the Internet anyway. Fellow council members complimented him for thinking "outside the box." Instead of accepting this myth, however, a Tacoma News Tribune reporter decided to visit the central library and its nine branches. He found something different. "Let's think inside the box", he argued, "because it is inside those bricks-and-mortar boxes where community lives. Tacoma's ten libraries are the living rooms of ten neighborhoods. They are places where latchkey kids can feel safe in the afternoons, where people without Internet access at home go online, where parents give their children the gift of reading." (Tacoma News Tribune, 2005).

On July 31, 2005, the Washington Post Magazine carried an article by Eric Wee that focused on the District of Columbia's Southeast Neighborhood Library, located in one of our Capitol's poorest neighborhoods. In the article Wee reports that every Tuesday night a homeless man named Conrad Cheek Jr. enters the library and sets up his chess board on one of the tables in the children's room. Wee immediately noticed a transformation taking place. "No more ignored pleas" for this homeless man, he writes. "No averted glances. During the next hour, people will 
look him in the eye. They'll listen to his words. In this down-at-the-heels library he's the teacher." Among his students was nine-year-old Ali Osman. As Wee watched this interaction, Ali's mother explained that her son's confidence had soared after playing with Conrad, that he was now bragging to friends about being a chess player. "We owe it all to Mr. Conrad", his mother said. "We love him." Wee reported that inside the Southeast Neighborhood Library, "They call him Mr. Conrad."

Other patrons frequenting the Library included Jane and Doug Alspach, who seventeen years earlier had moved to D.C. with their new-born daughter Sarah from Alexandria, Virginia, to get away from neighborhoods where most shopped J. Crew and drove Volvos. They liked the neighborhood because it had people of different races, classes and backgrounds. They liked the Library because.

"It's one of the last outposts where a cross section of people still come together. It's where Sarah was reading in groups with kids from wealthy families and those who were just getting by. It's where they gathered on holidays for parties, where they caught up with neighbors during the weekly story times. And it's a place that remembers them." Wee also noticed Catherine Stancil, a 69-year old functionally illiterate grandmother who every Saturday for the past year came to the library to meet with a volunteer, 30-year old attorney Karen Dees. Although Dees worried she was not doing a good job, Catherine disagreed. Wee reported Catherine "has started to feel different about herself. Her shame is gone." Proudly, she told Wee, "Now I feel that I'm as good as you." (Wee, 2005).

Without more research focus on library as place, we rob ourselves of a deeper understanding of the roles the library plays in its host community. At the same time, I would argue, by focusing so much on "the user in the life of the library" we automatically privilege transactional activities like information retrieval to a higher plane in the panoply of professional services than it actually deserves. In the past quarter century LIS discourse has regarded public realm activities as less important, marginally relevant, and peripheral to a professionally self-assumed infocentric research agenda. We have focused much more research attention on process than place, much more on the "user in the life of the library", not enough on "the library in the life of the user." From a user's perspective, life in a library is thoroughly social in many, many ways. Just ask Ray Bequet, Kim Crowley, Conrad Cheek, Jane Alspach, and Catherine Stancil.

There is no god or goddess of librarianship dictating what a library must be. History and tradition have defined it for our generation, but the recorded history passed down to us has, unfortunately, not sufficiently taken into consideration the library in the life of the user in the 
mix of forces that have shaped this civic institution. I've tentatively titled the book I mentioned in my initial remarks "This Hallowed Place: A People's History of the American Public Library." The first three words come from a Supreme Court opinion filed by Justice Abe Fortas. The case involved the arrests of five African Americans who had refused to leave the Audubon Regional Library in Clinton, Louisiana, on March 7, 1964, to protest the library's segregation policy. When police arrived, all five were arrested for "intent to provoke a breach of peace. "It is a sad commentary that this hallowed place in the Parish of East Feliciana bore the ugly stamp of racism”, Fortas wrote (Brown v. Louisiana, 1966). I argue that when he crafted this sentence into his majority opinion, he artfully gave voice to the deep feelings people have for their public libraries as places.

As an adolescent Jew in the 1920s, Fortas had found his hometown Memphis Public Library an "accessible and accommodating" "refuge" that gave him a "welcoming experience", this in the midst of a predominantly Protestant culture let him know he was unwelcome in so many other local places and spaces. But it was the same public library nineteen-year old African American Richard Wright was trying to access. As a $6^{\text {th }}$ grader in Jackson, Mississippi, in 1922, he used to marvel with his friends at articles in the Chicago Defender that "Lake Michigan Negroes" could go to public libraries and take out any book they wanted. Three years later he moved to Memphis. "Negroes were not allowed to patronize its shelves any more than they were the parks and playgrounds of the city", he wrote in his autobiography. Because he had previously gone into the library "to get books for white men on the job", he plotted: "Which of them would now help me to get books?" One morning he approached a white Irish Catholic he knew had a library card. "I want to ask you a favor", Wright whispered. "What is it?" "I want to read. I can't get books from the library. I wonder if you'd let me use your card?" The white man balked. "You're not trying to get me in trouble, are you, boy?" When asked what he wanted to read, Wright replied: "Mencken." Eventually, he agreed, and after pledging Wright not to "mention this to the other white men", gave the African American his wife's card. "That afternoon I addressed myself to forging a note. . 'Dear Madam: Will you please let this nigger boy - I used the word 'nigger' to make the librarian feel that I could not possibly be the author of the note- have some books by H.L. Mencken?" Wright's description of what happened thereafter follows:

"I entered the library as I had always done when on errands for whites, but I felt that I would somehow slip up and betray myself. I doffed my hat, stood a respectful distance from the desk, looked as unbookish as possible, and waited for the white patrons to be take care 
of. When the desk was clear of people, I still waited. The white librarian looked at me.

- 'What do you want, boy?'

- As though I did not possess the power of speech, I stepped forward and simply handed her the forged note, not parting my lips.

- 'What books by Mencken does he want?' she asked.

- 'I don't know, ma’am,' I said, avoiding her eyes.

- 'You're not using these books, are you?' She asked pointedly.

- 'Oh, no, ma’am. I can't read.'

The ploy worked; the librarian delivered copies of Mencken's Prejudices and A Book of Prefaces (Wright, 1937). Unlike Fortas the Jew living in a culture where anti-Semitism was somewhat muted but who nonetheless had open access to the Memphis Public Library, Wright the African American had to subvert the openly racist conventions around him to penetrate its space. Obviously, however, both valued "this hallowed place" highly, both fought to protect and enhance its accessibility for all community members later in life. Wright became a regular at the Chicago Public Library system's Cleveland Branch in the 1930s after he moved to the Windy City. Three decades later the Memphis Public Library served an essential role as public space in which the city's blacks and whites began forging racial harmony.

The latter part of my title comes from Howard Zinn's best selling, A People's History of the United States, which interprets the nation's history not from the top down--through the eyes of its economic, political and cultural leaders, but from the bottom up--through the eyes of domestic servants, war resisters, and fugitive slaves (Zinn, 1980). With "This Hallowed Place" I hope to accomplish something similar by deliberately avoiding a national story of library development as a point of departure, and instead allow the local libraries, their managers, and as much as possible their users to identify their particularities and speak memory to history. What I want, in short, is a focus not on the "user in the life of the library", but on "the library in the life of the user." Hopefully, this approach will create greater understanding of the multiple roles these ubiquitous institutions have played in their host communities over the generations. Preliminary findings already show that people have always used the American public library as "spatially anchored" public space where patrons seek "refuge", "hiding places", and "welcoming experiences." As "accessible and accommodating" places, they have provided neutral ground that helped "level" society by bringing together men, women, and children of 
all social classes and many races and ethnicities. They have also empowered their users by allowing them to come and go as they please, but at the same time they socialized diverse cultures by modeling the community's acceptable behaviors. They have provided space that fostered conversation where community got constructed in a variety of ways, including the facilitation of "imagined communities" in which occupants "meet" as groups mostly in their imagination (Anderson, 1983).

By taking a "library in the life of the user" perspective in my research on this "People's History of the American Public Library", I see "library as place" as a predominant historical consistency running all the way from the Boston Public Library that opened in 1854 to the Flathead Montana County Library experience with neo-Nazis and local protesters earlier this year. It looks to me like library as place has been crucial to the existence of the American public library for a century-and-a-half, and helps explain why the number of visitors to public libraries has increased every year for the past fifteen. I think it also helps us understand more deeply why people come out of the woodwork to protest attempts by local politicians to close their branch libraries. If the research on the public sphere I cited earlier is any indicator, the library as place means so much more to patrons than merely an information institution, and as a profession, until we expand our research agenda to include from a "library in the life of the user" perspective more investigations of what happens in all types of library spaces, we will continue to undervalue the library's role as place. As a phrase, "I Only Hate Broccoli" sounds cute, and innocent. On a placard at a protest rally against hatred and racism, however, it becomes an important message and a powerful political statement. History tells me this place we call "library" has rich tradition of providing the kind of safe and civil space in which statements like these can be delivered. What happened at the Flathead County Library tells me the tradition lives on.

\section{References}

[1] Anderson, Benedict. 1983. Imagined Communities: Reflections on the Origin and Spread of Nationalism. London: Verso.

[2] Buschman, John, \& Leckie, Gloria J. Eds. 2007. The Library as Place: History, Community, and Culture. Westport, CT: Libraries Unlimited. 
[3] Crowley, Kim. 2010. Personal Conversation with Wayne A. Wiegand, July 29.

[4] Habermas, Jurgen. 1989. The Structural Transformation of the Public Sphere: An Inquiry into a Category of Bourgeois Society. Cambridge, MA: Harvard University Press.

[5] Hausen, Jodi. 2008. "One for the Books: Ray Bequet Lends Help Hand to Youngsters at Library." Bozeman Daily Chronicle, July 1.

[6] Hiss, Tony. 1990. The Experience of Place. New York: Alfred A. Knopf.

[7] Kellogg, Arthur P. [n.d.]. "Small Town Rejuvenated: How a Social Center Has Succeeded New Community Spirit." Survey, 32: 32.

[8] Lancaster, F. Wilfrid. 1978. Toward Paperless Information Systems. New York: Academic.

[9] Leckie, Gloria J. 2004. "Three Perspectives on Libraries as Public Space." Feliciter, 6: 233236.

[10] Leckie, Gloria J., \& Hopkins, Jeffrey. 2002. "The Public Place of Central Libraries: Findings from Toronto and Vancouver." Library Quarterly, 72: 326-372.

[11] Lofland, Lyn H. 1998. The Public Realm: Exploring the City's Quintessential Social Territory. New Yorik: Aldine De Gruyter.

[12] Most, Linda R. 2009. The Rural Public Library as Place in North Florida: A Case Study of the Gadsden County Public Library System. Ph.D. Diss., School of Library and Information Studies, Florida State University.

[13] Oldenburg, Ray. 1997. The Great Good Place: Cafes, Coffee Shops, Community Centers, Beauty Parlors, General Stores, Bars, Hangouts, and How They Get You Through the Day. New York: Paragon House.

[14] Schudson, Michael. 1998. The Good Citizen: A History of American Civic Life. New York: The Free Press.

[15] Supreme Court of the United States. 1966. Brown v. Louisiana, 383 U.S. 131 (1966). Washington, DC: Supreme Court of the United States.

[16] Tacoma News Tribune. [online]. [cited 2005. 8. 1]. $\langle$ http://www.thenewstribune.com〉.

[17] Toffler, Alvin. 1970. Future Shock. New York: Random House.

[18] The Village Library's Opportunity. 1925. Wisconsin Library Bulletin, 21: 171-172.

[19] Wee, Eric L. 2005. "Shelf Life." The Washington Post Magazine, 15-18.

[20] Wiegand, Wayne A. 2005. "Library as Place." North Carolina Libraries, 63: 76-81.

[21] Wiegand, Wayne A. 2007. "Libraries and the Invention of Information." Simon Eliot and Jonathan Rose, Eds. A Companion to the History of the Book, 531-543. Malden, MA: 
74 한국문헌정보학회지 제 44 권 제 4 호 2010

Blackwell Publishing.

[22] Wright, Richard. 1937. Black Boy: A Record of Childhood and Youth, 214-217. New York: Harper \& Brothers.

[23] Zinn, Howard. 1980. A People's History of the United States. New York: Harper \& Row. 